\begin{tabular}{|l|l|l|}
\hline \multicolumn{2}{|c|}{ PublisherInfo } \\
\hline \hline PublisherName & $:$ & BioMed Central \\
\hline \hline PublisherLocation & $:$ & London \\
\hline \hline PublisherImprintName & $:$ & BioMed Central \\
\hline \hline
\end{tabular}

\title{
Engineering translocations
}

\begin{tabular}{|l|l|l||}
\hline \multicolumn{2}{|c|}{ ArticleInfo } \\
\hline \hline ArticleID & $:$ & l752 \\
\hline \hline ArticleDOI & $:$ & $10.1186 /$ gb-spotlight-20000830-01 \\
\hline \hline ArticleCitationID & $:$ & spotlight-20000830-01 \\
\hline \hline ArticleSequenceNumber & $:$ & 189 \\
\hline \hline ArticleCategory & $:$ & Research news \\
\hline ArticleFirstPage & $:$ & 1 \\
\hline \hline ArticleLastPage & $:$ & 2 \\
\hline \hline & $:$ & RegistrationDate : 2000-08-30 \\
ArticleHistory & $:$ & OnlineDate \\
\hline \hline ArticleCopyright & $:$ & BioMed Central Ltd2000-08-30 \\
\hline \hline ArticleGrants & $:$ & \\
\hline \hline ArticleContext & $:$ & 130591111 \\
\hline \hline
\end{tabular}




\section{Jonathan B Weitzman}

Email: JWeitzman@elabseurope.com

Many cancers (particularly leukemias and lymphomas) are associated with chromosomal translocations. The swapping of chromosomal ends can activate oncogenes adjacent to the breakpoints, disrupt important control genes or generate novel fusion proteins that have deleterious effects. Two papers in the 15th August EMBO Reports describe use of the Cre-lox targeted recombinase system to recapitulate cancer translocations in mice. LoxP recognition sites were introduced into mice at chromosomal locations corresponding to known human translocation breakpoints. Interchromosomal translocations were then achieved by crossing these mice with animals expressing the Cre recombinase, which drives recombination between the two inserted loxP sites. In this way, the two groups were able to create Mll-Af9 (Collins et al., EMBO Reports 2000, 1:127-132) and AML1-ETO (Buchholz et al., $E M B O$ Reports 2000, 1:133-139), two fusion genes that are observed in acute leukemias in man. The demonstrated ability to 'cut-and-paste' chromosomes should lead to the generation of better animal models for studying specific malignancies.

\section{References}

1. Chromosomal translocations in human cancer.

2. Embo reports, [http://www.embo-reports.oupjournals.org/]

3. Independent control of immunoglobulin switch recombination at individual switch regions evidenced through Cre-loxP-mediated gene targeting. 